\title{
ANALISIS MASLAHAH TERHADAP WAKAF MUAQQAT (STUDI PASAL 1 AYAT 1 UU NO. 14 TAHUN 2004 TENTANG WAKAF)
}

\author{
Oleh: Makinudin \\ makinudin027@gmail.com \\ UINSA SURABAYA
}

\begin{abstract}
Abstraksi
Wakaf merupakan salah satu bagian dari sedekah, yang dalam hadis diberi sifat dengan lafal "jariyyah" setelah lafal "sadaqah", dan oleh ulama dianggap sedekah yang paling utama. Wakaf diundangkan melalui al-Qur'an dan al-Hadith, dan dipraktekkan sejak zaman nabi Muhammad saw. sampai sekarang. Bahkan, di Indonesia, sejak tahun 2004 telah ada undang-undang tentang wakaf yang menyempurnakan peraturan-peraturan sebelumnya.

Pada umumnya, masyarakat Islam beranggapan bahwa wakaf itu bersifat muabbad (berlaku selamanya), tidak muaqqat (dibatasi waktunya), sehingga jika wakif telah mengucapkan ikrar wakaf, maka benda yang diwakafkan itu lepas dari miliknya, tidak dapat ditarik kembali. Hal ini didasarkan, bahwa mereka bermazhab Shafi'i, sebagaimana kitab-kitab dan buku-buku mereka yang dibaca dan dipahami, sehingga jika ada pendapat lain, mereka menolaknya, padahal wakaf itu merupakan masalah ijtihad.

Pasal 1 ayat 1 Undang-undang Nomor 41 Tahun 2004 Tentang Wakaf menjelaskan bahwa wakaf itu ada yang muabbad dan muaqqat, berbeda dengan peraturan sebelumnya, yaitu Peraturan Pemerintah Nomor 28 Tahun 1977 Tentang Perwakafan Tanah Milik dan Kompilasi Hukum Islam, dengan cara menggabungkan beberapa mazhab fiqh, Malikiyyah, Hanafiyyah, Shafi'iyyah, dan Malikiyyah dengan cara talfiq .

Pemberlakuan wakaf muaqqat sesuai dengan ulama Malikiyyah yang menyatakan bahwa benda wakaf tidak lepas dari kepemilikan wakif dan Hanafiyyah, yang berpendapat bahwa wakaf itu seperti akad 'ariyah (pinjaman), yang sewaktuwaktu dapat ditarik kembali. Sedangkan, dari sisi maslahah, wakaf muaqqat, yang merupakan bagian dari Pasal 1 ayat 1 UU No. 41 Tahun 2004 termasuk dalam maslahah hajiyyah (sekunder), yang bersifat menyempurnakan maslahah daruriyyah (primer) terkait dengan memelihara keturunan (muhafazah 'ala naslal$n a s a b)$, sehingga terhindar dari kefakiran keluarga wakif.
\end{abstract}

Kata Kunci: Wakaf muabbad dan muaqqat, UU No. 1 Tahun 2004, daruriyyah, hajiyyah. 


\section{A. Latar Belakang Masalah}

Dalam Hadis dinyatakan bahwa jika anak cucu Adam meninggal dunia, maka seluruh amalnya akan terputus kecuali tiga perkara, yaitu sedekah jariyyah atau ilmu yang bermanfaat atau atau anak saleh yang selalu mendo'akan orang tuanya. Wakaf merupakan perwujudan sedekah jariyyah berupa harta benda bernilai yang dilakukan seseorang atau lembaga untuk mengharap keridlaan Allah swt., baik diberikan kepada perorangan atau lembaga, untuk sementara (muaqqat) maupun selama-lamanya (muabbad).

Umat Islam Indonesia dari masa ke masa telah melakukan wakaf untuk kepentingan umum (disebut waqaf khayri), disamping wakaf untuk keluarga (disebut waqaf dhurri). Pada umumnya pewakafan diberlakukan untuk waktu selama-lamanya dan pewakafan dilakukan pada saat orang yang mewakafkan (waqif) dalam keadaan sehat. Pewakafan dalam keadaan demikian tersebut berdasarkan ajaran yang menyatakan bahwa sedekah yang paling baik adalah sedekah sewaktu masih dalam keadaan sehat. Namun demikian, ada keadaan lain, misalnya, pada usia tua waqif atau setelah waqif meninggal dunia ada keadaan dimana keluarga waqif dalam keadaan lemah. Lebih-lebih kelemahan tidak mampu membiayai pendidikan anak-cucunya sampai pada pendidikan tinggi yang membutuhkan biaya besar. Ada juga yang pada usia tua, wa> qif sakit-sakitan dan membutuhkan biaya perawatan dan pengobatan, sementara hartanya telah habis diwakafkan untuk waqaf khayri.

Melihat kenyataan tersebut, penulis tertarik membahas wakaf muaqqat. Pada umumnya umat Islam Indonesia, mayoritas bermazhab Shafi'i, belum memahami peruntukkan harta wakaf muaqqat yang berbeda dengan wakaf yang sudah berlaku sampai sekarang (waqaf muabbad). Sementara itu pemerintah Indonesia telah memberlakukan dua macam wakaf muabbad dan wakaf muaqqat dalam UU No. 41 Tahun 2004. Untuk itu, masalah yang dirumuskan dalam pembahasan ini adalah (1) Bagaimana pandangan ulama fiqh terhadap wakaf muaqqat, dan (2) Bagaimana tinjauan maslahah terhadap wakaf muaqqat dalam pasal 1 ayat 1 Undang-Undang Nomor 41 Tahun 2004. Dengan dua rumusan tersebut diharapkan umat Islam akan lebih terdorong untuk mewakafkan harta benda mereka dengan wakaf muaqqat, di samping selalu wakaf muabbad sebagaimana yang sudah berjalan di kalangan umat Islam Indonesia yang bermazhab Sha>fi' $i>$, sehingga nilai wakaf ini tidak hanya kembali kepada wa>qif, tetapi bisa kembali juga kepada keluarga mereka.

\section{B. Wakaf Muaqqat}

1. Pengertian Wakaf

Menurut bahasa al-waqf bermakna al-habs an al-tasarruf (menahan melakukan sesuatu). Sedangkan, menurut istilah shara', al-waqf (dalam bahasa Indonesia menjadi wakaf) mempunyai beberapa pengertian sebagai berikut:

a. Menurut Imam Abu Hanifah

Wakaf adalah menahan suatu benda yang secara hukum masih dimiliki oleh orang yang mewakafkan (waqif) dan bersedekah dengan manfaat yang 
diperlukan pada jalan kebaikan. ${ }^{1}$ Pengertian ini menunjukkan bahwa barang yang diwakafkan tidak lepas dari kepemilikan orang yang mewakafkan, sehingga ia dapat ditarik kembali dan/atau dapat dijual. Hal ini karena menurut Abu Hanifah bahwa wakaf itu merupakan sesuatu yang boleh (jaiz) dan tidak tetap sebagaimana akad pinjaman ('ariyah). Artinya, sewaktu-waktu obyeknya dapat ditarik kembali atau dapat dilakukan apa saja oleh wakif karena belum efektif atau lazim.

Menurut Abu Hanifah, wakaf itu baru efektif atau tidak dapat ditarik kembali oleh wakif jika telah dilakukan salah satu dari hal-hal berikut:

1) Ada keputusan dari hakim sewaktu terjadi persengketaan antara wakif dan nazhir dan pihak nazhir sebagai pihak yang menang.

2) Ada ketergantungan terjadinya wakaf yang dilakukan oleh hakim terhadap wakif sebagaimana wasiat. Artinya, sebelum wakif meninggal dia dapat menarik kembali objek wakaf, sedangkan jika ia sudah meninggal dunia maka ahli waris wakif tidak dapat menarik kembali.

3) Obyek wakaf telah dijadikan atau diperuntukkan masjid dan telah dipisahkan dari kepemilikan wakif serta dilakukan adzan untuk shalat. ${ }^{2}$

b. Mayoritas ulama Shafi'iyah dan Hanabilah

Wakaf ialah menahan harta benda yang dapat diambil manfaatnya serta kekal bendanya dengan memutuskan pemakaian (kepemilikan) dari wakif pada jalan yang baik semata-mata untuk mendekatkan diri kepada Allah. ${ }^{3}$ Dengan pengertian ini, harta benda wakif telah keluar dari kepemilikan wakif dan menjadi milik Allah. Bagi wakif dilarang menggunakan harta wakaf dan hasilnya digunakan untuk amal karena Allah atau tabarru' (amal sosial).

c. Malikiyah

Wakaf adalah menjadikan manfaat benda yang dimiliki pemilik (wakif) walaupun kepemilikannya melalui sewa atau menjadikan hasil dari miliknya kepada orang yang berhak dengan bentuk penyerahan sesuai dengan jangka waktu yang dikehendaki oleh wakif. ${ }^{4}$ Dengan pengertian ini, pemilik (wakif) menahan obyek (benda) yang diwakafkan dari segala bentuk pemakaian dan diperuntukkan untuk amal kebaikan sesuai dengan jangka waktu yang telah ditentukan oleh wakif. Artinya, wakif masih tetap memiliki benda yang telah diwakafkan, yang diwakafkan hanya manfaat atau hasilnya saja, baik itu milik wakif itu sendiri atau wakif hanya mempunyai hak mengambil manfaat karena hartanya berasal dari akad penyewaan. Oleh karena itu, menurut Malikiyah, wakaf tidak dapat memutus hak kepemilikan wakif dari benda yang diwakafkan.

d. Wakaf menurut Peraturan Perundang-undangan sebagai berikut:

1) Peraturan Pemerintah No. 28 Tahun 1977 tentang Perwakafan Tanah Milik

\footnotetext{
${ }^{1}$ Wahbah al-Zuhayli, al-Fiqh al-Islām wa Adillatuh. vol. 9. (Beirut: Dar al-Fikr, 1997), 154.

${ }^{2}$ Ibid.

${ }^{3}$ Ibid. 155.

${ }^{4}$ Ibid.
} 
Wakaf adalah perbuatan hukum seseorang atau badan hukum yang memisahkan sebagian dari harta kekayaannya yang berupa tanah milik dan melembagakannya untuk selama-lamanya untuk kepentingan peribadatan atau keperluan umum lainnya sesuai dengan ajaran agama Islam (pasal 1 ayat 1$)^{5}$. Pengertian ini hanya tertuju pada wakaf muabbad, tidak wakaf muaqqat.

2) Kompilasi Hukum Islam

Wakaf adalah perbuatan hukum seseorang atau kelompok atau badan hukum yang memisahkan sebagian dari benda miliknya dan melembagakannya untuk selama-lamanya guna kepentingan ibadat atau keperluan umum lainnya sesuai dengan ajaran agama Islam (pasal 215, ayat 1) ${ }^{6}$. Pengertian ini hanya mengarah pada berlakunya wakaf muabbad, tidak muaqqat.

3) Undang-undang No. 41 Tahun 2004 tentang Wakaf

Wakaf adalah perbuatan hukum wakif untuk memisahkan dan/atau menyerahkan sebagian dari harta miliknya untuk dimanfaatkan selamanya atau untuk jangka waktu tertentu sesuai dengan kepentingannya guna kepentingan ibadah dan atau kesejahteraan umum menurut syariat (pasal 1 ayat 1$)^{7}$. Pengertian ini mengarah berlakunya wakaf, baik wakaf muabbad maupun wakaf muaqqat.

Jika diperhatikan secara seksama tentang pengertian wakaf, baik menurut pendapat ahli fiqh maupun menurut peraturan perundang-undangan Republik Indonesia, maka dapat dipahami sebagai berikut:

1) Wakaf menurut pasal 1 ayat (1) PP Nomor 28 Tahun 1977 jo. pasal 215 ayat (1) Kompilasi Hukum Islam sama dengan pendapat mayoritas ulama, Shafi'iyah dan Hanabilah, yaitu:

- Benda yang diwakafkan telah lepas dari milik wakif.

- Benda wakaf tidak dapat ditarik kembali oleh wakif.

- Benda wakaf diperuntukkan kebaikan atau kepentingan umum sesuai dengan ajaran Islam.

2) Wakaf menurut pasal 1 ayat (1) UU Nomor 4 Tahun 2004 sama dengan pendapat Hanafiyah dan Malikiyah, yaitu:

- Benda yang diwakafkan belum lepas dari pemilik wakaf, boleh ditarik kembali oleh wakif sebagaimana pinjaman ('ariyah).

- Benda yang diwakafkan tidak harus miliknya wakif sendiri, tetapi dapat juga dari tanah sewa.

- Benda yang diwakafkan diperuntukkan untuk kebaikan.

3) Benda yang diwakafkan terbatas pada benda tidak bergerak, berupa tanah milik (PP Nomor 28 Tahun 1977). Sedangkan Kompilasi Hukum Islam dan UU Nomor 41 Tahun 2004, obyek (benda) yang diwakafkan dapat berupa

\footnotetext{
${ }^{5}$ Suparman Usman, Hukum Perwakafan di Indonesia. (Serang: Darul Ulum, 1999), 214.

${ }^{6}$ Abdurrahman, Kompilasi Hukum Islam di Indonesia (Jakarta: Akademika Prassindo, 1992). 165.

${ }^{7}$ Abdul Ghafur Anshori, Hukum dan Praktik Perwakafan di Indonesia. (Yogyakarta: PDOP, 2006), 150 .
} 
benda bergerak dan yang tidak bergerak. Bahkan Undang-Undang Nomor 41 Tahun 2004 menyebutkan bahwa obyek wakaf dapat berupa hasil atau manfaat dari benda yang masih tetap dimiliki wakif.

Di dalam Undang-Undang Nomor 41 Tahun 2004 tentang Wafaf dijelaskan bahwa obyek wakaf tidak hanya berupa tanah milik sebagaimana dalam PP No. 28 Tahun 1977. Akan tetapi, obyek wakaf lebih luas sebagaimana Pasal 1 (5) menyatakan bahwa harta benda wakaf adalah harta benda yang memiliki daya tahan lama dan/atau manfaat jangka panjang serta mempunyai nilai ekonomi menurut syari'ah yang diwakafkan oleh wakif. Lebih lanjut Pasal 16 (1) dinyatakan bahwa harta benda wakaf terdiri dari atas benda bergerak dan tidak bergerak. Sementara itu, Pasal 16 (3) dinyatakan bahwa benda bergerak sebagaimana pada ayat 1 huruf $b$ adalah benda yang tidak bisa habis karena konsumsi, yang meliputi uang, logam mulia, surat berharga, kendaraan, hak atas kekayaan intelektual, hak sewa, benda bergerak lain sesuai dengan ketentuan syari'ah dan peraturan perundang-undangan yang berlaku. ${ }^{8}$

Wakif dapat mewakafkan benda bergerak berupa uang melalui lembaga keuangan Syari'ah yang ditunjuk oleh menteri (Pasal 28) dan lebih lanjut dalam Pasal 29 ayat 2 dinyatakan bahwa wakaf benda bergerak berupa uang sebagaimana dimaksud dalam ayat 1 diterbutkan dalam bentuk sertifikat wakaf uang dan pada ayat 3 dinyatakan bahwa sertifikat wakaf yang dimaksudkan pada ayat 2 diterbitkan dan disampaikan oleh lembaga keuangan Syari'ah kepada wakif dan nazhir sebagai bukti penyerahan harta wakaf. ${ }^{9}$

Pasal 29 ayat 2 SK Dir. BI No. 32134/KEP/DIR Tentang Bank Umum Berdasarkan Prinsip Syari'ah dinyatakan bahwa Bank dapat bertindak sebagaimana lembaga baitul mal, yaitu menerima dana yang bersal dari zakat, infaq, shadaqah, wakaf, hibah atau dana social lainnhya dan menyalurkannya kepada yang berhak dalam bbentuk santunan dan/atau pinjaman kebajikan (qardl al-h(san). Kemudian diperkuat juga dengan SK Dir BI No. 32136/KEPIDIR Tentang Bank Perkrediktan Rakyat Berdasarkan Prinsip Syari'ah, yang menyatakan bahwa BPRS dapat bertindak sebagai lembaga baitul mal, yaitu menerima dana yang bersal dari zakat, infaq, waqaf, hibah atau dana sosial lainnya dan menyalurkannya kepada yang berhak dalam bentuk santunan dan/atau pinjaman kebajikan (qardul hasan). Dengan demikian, Bank Syari'ah dapat mengambil peran sebagai penerima dan penyalur dana wakaf, sedangkan peran Bank Syari'ah sebagai pengelola dana wakaf tidak disebutkan secara eksplisit. ${ }^{10}$

Dalam fiqh klasik, wakaf itu sering dicontohkan dengan wakaf ahli atau dhurri (keluarga) sebagaimana dalam kitab al-Taqrib atau Fath al-Qarib, tidak tampak ada pembahasan tentang wakaf khairi (wakaf untuk kepentingan umum). Sedangkan, dalam fiqh kontemporer diketemukan pembagian wakaf ke dalam wakaf ahli dan khairi sebagaimana dalam kitab Fiqh al-Sunnah karya Sayyid Sabiq, al-Fiqh al-Islam karya Wahbah al-Zuhayli. Hal ini berbeda dengan wakaf yang ada pada PP Nomor 28 Tahun 1977, Kompilasi Hukum Islam, dan UU

\footnotetext{
${ }^{8}$ Departemen Agama, Bunga Rampai Perwakafan (Jakarta: Direktorat Jenderal Bimbingan Masayarakat Direktorat Pemberdayaan Wakaf, 2006), 40.

${ }^{9}$ Ibid. 41.

${ }^{10}$ Ibid., 39.
} 
Nomor 41 Tahun 2004, termasuk juga wakaf di negara-negara muslim, yang hanya untuk wakaf khayri.

Dalam satu segi, wakaf ahli (dhurri) dianggap sangat baik, karena wakif akan mendapatkan dua kebaikan, yaitu kebaikan dari ibadah wakafnya dan menyambung kekeluargaan terhadap keluarga yang diberi harta wakaf (mawquf 'alayh), Akan tetapi, pada segi lain, wakaf ahli sering menyebabkan masalah, seperti bagaimana jika anak cucu yang ditunjuk tidak ada lagi? Siapa yang berhak mengambil manfaat dari harta benda wakaf? Bagaimana jika anak cucu wakif yang menjadi tujuan wakaf berkembang, sehingga menyulitkan cara menyamakan pembagian hasil dari harta wakaf? Untuk itu, pada perkembangannya, wakaf ahli dianggap kurang dapat memberikan manfaat bagi kesejahteraan umum, karena sering menimbulkan kekaburan dalam pengelolaan dan pemanfaatan wakaf oleh keluarga yang diserahi harta wakaf. Karena itu, di beberapa negara tertentu seperti Mesir, Turki, Maroko, dan Aljazair, termasuk Indonesia wakaf keluarga telah dihapuskan, karena pertimbangan dari berbagai segi, tanah-tanah wakaf dalam bentuk ini dianggap tidak produkif. ${ }^{11}$

\section{Unsur-unsur wakaf}

Dalam wakaf terdapat beberapa unsur pokok berupa (1) al-waqif (orang yang mewakafkan), (2) al-mawquf (benda yang diwakafkan), (3) al-mawquf 'alayh (tujuan wakaf), (4) sighat atau pernyataan ikrar wakaf, sebagaimana pendapat mayoritas ulama. Hal ini berbeda dengan pendapat Hanafiyah yang menyatakan bahwa unsur (rukun) wakaf itu hanya satu, yaitu sighat. ${ }^{12}$

Rukun wakaf yang berupa al-mawquf 'alayh terkadang diartikan dengan tujuan wakaf sebagaimana tulisan Ahmad Rafiq dalam Hukum Islam di Indonesia dan Umar Said dalam Hukum Islam di Indonesia tentang warisan, wasiat, hibah dan wakaf. Dalam hal ini, tujuan wakaf adalah:

a. Untuk mencari keridlaan Allah, termasuk di dalmnya segala macam usaha untuk menegakkan agama Islam seperti mendirikan tempat beribadah kaum muslimin, kegiatan dakwah, dan pendidikan Islam.

b. Untuk kepentingan masyarakat sepertu membantu fakir miskin, orang-orang terlantar, kerabat, mendirikan sekolah, dan asrama anak-yatim. ${ }^{13}$

Pemahaman mawquf 'alayh dengan tujuan wakaf dimungkinkan karena dalam hukum Islam di Indonesia hanya digunakan wakaf khayri, bukan ahli. Akibatnya wakaf itu hanya menjadi hak Allah (kepentingan umum). Oleh karena itu, perlu ada nazhir yang dalam Kompilasi Hukum Islam (KHI) dinyatakan bahwa nazhir harus memenuhi syarat-syarat:

(1) Nazhir sebagaimana dimaksud dalam pasal 215 ayat (4) terdiri atas perorangan yang harus memenuhi syarat-syarat: ${ }^{14}$

\footnotetext{
11 Departemen Agama, Fiqih Wakaf (Jakarta: Proyek Peningkatan Zakat dan Wakaf Jenderal Bimas Islam dan Penyelenggaraan Haji, 2006), 15-16.

${ }^{12}$ al-Zuhayli. al-Fiqh. 159.; al-Sharqawi. t.th. al-Sharqawi 'ala al-Tahrīr. Juz 2. Singapura: al-Haramain. 173.

${ }^{13}$ Ahmad Rofiq, Hukum Islam di Indonesia (Jakarta: RajaGrafindo Persada, 2003), 497; Said, Umar.1997. Hukum Islam di Indonesia. Surabaya: CV Cempaka. 173; Usman, Hukum. 32.

${ }^{14}$ Pasal 219 KHI jo. pasal 6 PP Nomor 28 Tahun 1977.
} 

a. Warga negara Indonesia
b. Beragama Islam
c. Sudah dewasa
d. Sehat jasmani dan rohani
e. Tidak berada di bawah pengampuan
f. Bertempat tinggal di kecamatan tempat letak benda yang diwakafkan.

(2) Jika berbentuk badan hukum, maka nazhir hars memenuhi persaryaratan sebagai berikut:

a. Badan hukum Indonesia dan berkedudukan di Indonesia.

b. Mempunyai perwakilan di kecamatan tempat letak benda yang diwakafkan.

Dengan melihat perbedaan makna dan maksud ma'qud alayh tersebut sangat tepat sekali dikemukakan unsur-unsur wakaf dalam Undang-undang No. 41 Tahun 2004 tentang wakaf secara rinci, sebagaimana tercantum dalam Pasal 6, yaitu wakaf dilaksanakan dengan memenuhi unsur-unsur wakaf, yaitu (a) wakif, (b) nazhir, (c) harta benda wakaf, (d) ikrar wakaf, (e) peruntukan harta benda wakaf, (f) jangka waktu wakaf. ${ }^{15}$

Jangka waktu wakaf dalam fiqh klasik (Shafi'iyah) tidak dikenal dengan jangka waktu, karena wakaf itu untuk Allah dan berlaku selama-lamanya setelah ada ikrar dari wakif. Artinya, wakif tidak boleh membatasi peruntukan herta benda wakaf dalam jangka tertentu, kecuali $\mathrm{H}$ \}anafiyah dan Malikiyah yang boleh membatasi peruntukan wakaf yang kemudian dipakai dalam UU No. 41 Tahun 2004. Akan tetapi, jika wakaf itu berupa tanah dan sudah dibuatkan akta ikrar wakaf serta sudah menjadi sertifikat tanah wakaf, maka tidak dapat ditarik kembali, sebagaimana pendapat Hanfiyah. Artinya, walaupun Hanafiyah beranggapan bahwa wakaf tidak bersifat luzum (mengikat) karena ia seperti 'ariyah (pinjaman), tetapi jika sudah diputuskan hakim atau diatur oleh pemerintah maka menjadi mengikat (luzum).

Wakif diatur dalam pasal 7 dan 8 UU No. 41 Tahun 2004 dengan:

a. Macam-macam wakif yang meliputi wakif perseorangan, organisasi, badan hukum diatur dalam pasal 7.

b. Syarat-syarat dari masing-masing wakif diatur dalam pasal 8 .

Nazhir diatur dalam pasal 9,10, 11, 12, 13, dan 14 UU No. 41 Tahun 2004:

a. Bentuk nazhir diatur dalam pasal 9

b. Syarat-syarat nazhir diatur dalam pasal 10

c. Tugas-tugas nazhir diatur dalam pasal 11,12 , dan 13

d. Perbuatan nazhir diatur dalam pasal 14.

Harta benda wakaf diatur dalam pasal 15 dan 16 UU No. 41 Tahun 2004:

\footnotetext{
${ }^{15}$ Abdul Ghofur Anshori. Hukum. 150.
} 
a. Syarat harta benda yang diwakafkan diatur dalam pasal 15

b. Macam-macam harta benda wakaf, bergerak atau tidak bergerak diatur dalam pasal 16, termasuk cakupan dari benda bergerak dan tidak bergerak

Ikrar wakaf diatur dalam 17,18, 19, 20, dan 21 UU No. 41 Tahun 2004:

a. Pelaksanaan ikrar wakaf diatur dalam pasal 17, 18, dan 19.

b. Saksi dalam ikrar wakaf diatur dalam pasal 20.

c. Penuangan ikrar wakaf diatur dalam pasal 21.

Peruntukan harta wakaf diatur dalam pasal 22 dan 23 UU No. 41 Tahun 2004:

a. Peruntukan wakaf sesuai dengan tujuan dan fungsi wakaf diatur dalam pasal 22

b. Penetapan peruntukan diatur dalam pasal 23.

Dalam pasal 10 PP No. 28 Tahun 1977 ditambahkan beberapa ayat sebagai berikut:

(2) Bupati/walikotamadya Kepala Daerah c.q Kepala Sub Direktorat Agraria setempat, setelah menerima permohonan tersebut dalam ayat (1) mencatat perwakafan tanah milik yang bersangkutan pada buku tanah dan sertifikatnya.

(3) Jika tanah milik yang diwakafkan belum mempunyai sertifikat, maka pencatatan yang dimaksud dalam ayat (2) dilakukan setelah untuk tanah tersebut dibuatkan sertifikatnya.

(4) Oleh Menteri Dalam Negeri diatur tata cara pencatatan perwakafan yang dimaksud dalam ayat (2) dan (3).

(5) Setelah dilakukan pencatatan perwakafan tanah milik dalam buku tanah dan sertifikatnya seperti dimaksud ayat (2) dan (3), maka nazhir yang bersangkutan wajib melaporkannya kepada pejabat yang ditunjuk Menteri Agama. ${ }^{16}$

Tambahan dalam pasal 10 PP 28 Tahun 1977 tersebut sebagai konsekuensi PP ini dikeluarkan yang tujuannya untuk mengatur perwakafan tanah milik. Sementara itu, KHI lebih bersifat umum dan tidak membatasi harta benda yang diwakafkan, yang merupakan langkah maju tentang perwakafan di Indonesia, tidak hanya yang tidak bergerak saja.

\section{Tata Cara Perwakafan Tanah}

Dalam Kompilasi Hukum Islam pasal 203 telah dijelaskan tantang tata cara perwakafan sebagai berikut:

(1) Pihak yang hendak mewakafkan dapat menyatakan ikrar wakaf di hadapan Pejabat Pembuat Akta Ikrar Wakaf untuk melaksanakan ikrar wakaf;

(2) Isi dan bentuk ikrar wakaf ditetapkan oleh Menteri Agama

(3) Pelaksanaan ikrar, demikian pula pembuatan Akta Ikrar wakaf, dianggap sah jika dihadiri dan disaksikan oleh sekurang-kurangnya 2 (dua) orang saksi.

${ }^{16}$ Usman. Hukum. 217. 
(4) Dalam melaksanakan ikrar seperti dimaksud ayat (1) pihak yang mewakafkan diharuskan menyerakan kepada Pejabat yang tersebut dalam pasal 215 ayat (6), surat-surat sebagai berikut:

a. Tanda bukti pemilikan harta benda

b. Jika yang diwakafkan berupa benda tidak bergerak, maka harus disertai surat keterangan dari kepala desa yang diperkuat oleh camat setempat yang menerangkan pemilikan benda tidak bergerak dimaksud.

c. Surat atau dokumen tertulis yang merupakan kelengkapan dari benda tidak bergerak yang bersangkutan. ${ }^{17}$

Pasal 223 KHI ini identik dengan pasal 9 PP No. 28 Tahun 1977 dengan penambahan huruf d izin dari Bupati/Walikotamadya Kepala Daerah c.q Kepala Sub Direktorat Agraria setempat (sekarang Kepala Badan Pertanahan) ${ }^{18}$

Setelah ikrar wakaf dilaksanakan dan diterangkan dalam Akta Ikrar wakaf, langkah selanjutnya diatur dalam pasal $224 \mathrm{KHI}$ :

"Setelah akta ikrar wakaf dilaksanakan sesuai dengan ketentuan pasal 223 ayat (3) dan (4), maka Kepala Kantor Urusan Agama kecamatan atas nama nazhir yang bersangkutan diharuskan mengajukan permohonan kepada camat untuk mendaftar perwakafan benda yang bersangkutan guna menjaga ketentuan dan kelestariannya."19

\section{Pelaksanaan Sertifikat Tanah Wakaf}

Dalam kamus besar bahasa Indonesia dijelaskan bahwa sertifikat adalah tanda atau surat keterangan (pernyataan tertulis) atau tercetak dari orang yang berwenang yang dapat digunakan sebagai bukti suatu kejadian. Sedangkan sertifikat tanah adalah surat bukti pemilikan tanah yang dikeluarkan oleh instansi yang berwenang mensertifikatkan atau mencatatkan (tanah, sawah) dalam bentuk sertifikat. $^{20}$

Sebelum berlakunya undang-undang pokok Agraria, bukti hak atas tanah bagi orang yang berhak berupa surat bukti hak hak yang diberikan oleh pejabat oversschijvings ambtenaar yang dikenal dengan akta balik nama untuk tanahtanah yang tunduk pada hukum perdata Barat. Sedangkan untuk tanah yang tunduk pada hukum adat tidak dikenal suatu alat bukti dalam bentuk tertulis, tetapi masyarakat awam beranggapan bahwa surat (tanda bukti) pembayaran pajak (verponding) itu sebagai tanda bukti hak atas tanah. ${ }^{21}$

Setelah berlakunya UUPA Nomor 5 Tahun 1960 dengan PP Nomor 10 Tahun 1961 tentang Pendaftaran Tanah, semua tanah di wilayah Republik Indonesia diperintahkan untuk didaftarkan dan bagi mereka yang berhak atas tanah akan memperoleh tanda bukti pemilikan yang mempunyai kekuatan pembuktian yang kuat. Tanda bukti tersebut dikenal dengan nama sertifikat, yaitu salinan buku

\footnotetext{
${ }^{17}$ Abdurrahman. Kompilasi. 169.

${ }^{18}$ Usman. Hukum. 217.

${ }^{19}$ Abdurrahman. Kompilasi. 169.

${ }^{20}$ Tim Redaksi, 1996. Kamus Besar Bahasa Indonesia, cet. ke-7. Jakarta: Balai Pustaka. 928.

${ }^{21}$ Surini Dahlan Sjarif, Intisari Hukum Benda (Jakarta: Ghalia Indonesia, 1984), 24.
} 
tanah atau surat ukur setelah dijahit menjadi satu bersama-sama dengan suatu kertas sampul.

Sertifikat tanah tidak akan diperoleh tanpa melalui pembuatan akta dahulu. Dalam hal itu, sejak diberlakukannya UUPA No. 5 Tahun 1960, maka segala sesuatu aturan yang mengenai bumi, air, dan kekayaan alam yang terkandung di dalamnya yang termuat dalam KUH Perdata dihapuskan, kecuali mengenai aturan-aturan mengenai hipotik. Peraturan pemerintah Nomor 10 Tahun 1961 dalam pasal 19 diatur:

“Tiap-tiap perjanjian yang dimaksud memindahkan hak atas tanah, memberikan sesuatu hak baru atas tanah, menggadaikan atau meminjam uang dengan hak atas tanah sebagai tanggungan harus dibuktikan dengan suatu akta yang dibuat oleh atau di hadapan pejabat yang ditunjuk oleh Menteri Agraria (Mendagri) ${ }^{22}$

Akta ialah surat tanda bukti berisi pernyataan (keterangan, pengakuan, keputusan, dan sebagainya) tentang peristiwa hukum yang dibuat menurut peraturan yang berlaku, disaksikan dan disahkan oleh pejabat resmi. Sedangkan akta autentik ialah akta yang dibuat oleh atau di hadapan pejabat umum yang berwenang membuat akta dalam bentuk yang ditentukan undang-undang. ${ }^{23}$

Akta ini banyak bentuknya, yaitu akta jual beli, akta tukar menukar, akta pemisahan dan pembagian akta, pembagian harta warisan, akta pemasukan dalam perseroan terbatas, akta nikah dan akta wakaf.

Wakaf benda bergerak berupa uang dapat dilihat UU No. 41 Tahun 2004 sebagai berikut:

Pasal 28 : Wakif dapat mewakafkan benda bergerak berupa uang melalui lembaga keuangn syari'ah yang ditunjuk oleh Menteri.

Pasal 29 : (1) Wakaf benda bergerak berupa uang sebagaimana dimaksud dalam Pasal 28 dilaksanakan oleh wakif dengan pernyataan kehendak wakif yang dilakukan tertulis;

(2) Wakaf benda bergerak berupa uan sebagaimana dimaksud pada ayat (1) diterbitkan dalam bentuk sertifikat wakaf uang;

(3) Sertifikat wakaf uang sebagaimana dimaksud pada ayat (2) diterbitkan dan disampaikan oleh lembaga keuangan syari'ah kepada wakif dan nazhir sebagai bukti penyerahan harta benda wakaf.

Pasal 30 : Lembaga keuangan syari'ah atas nama nazhir mendaftarkan harta benda wakaf berupa uang kepada Menteri selambat-lambatnya 7 (tujuh) hari sejak diterbitkannya Sertifikat Wakaf Uang.

Pasal 31 : Ketentuan lebih lanjut mengenai wakaf benda bergerak berupa uang sebagaimana dimaksud dalam Pasal 28, Pasal 29, dan Pasal 30 diatur dengan Peraturan Pemerintah. ${ }^{24}$

\footnotetext{
22 Ibid. 23.

${ }^{23}$ Redaksi. Kamus. 19.

${ }^{24}$ Anshori, Hukum, 159-160. Ketentuan wakaf benda bergerak berupa uang ini sejalan dengan fatw Majlis Ulama Indonesia pada tahun 2002 yang isinya membolehkan wakaf uan.
} 
Ikrar wakaf merupakan salah satu dari unsur wakaf dituangkan dalam akta ikrar wakaf (Pasal 21 ayat 1). Kemudian PPAIW (Pejabat Pembuat Akta Ikrar Wakaf) atas nama Nazhir mendaftarkan harta benda wakaf kepada instansi yang berwenang paling lambat 7 (tujuh) hari sejak akta ikrar wakaf ditandatangani (Pasal 32). Sementara itu, yang dimaksud dengan instansi yang berwenang di bidang tanah wakaf adalah badan pertanahan nasional dan untuk benda bergerak selain uang adalah instansi yang terkait dengan tugas pokoknya (Penjelasan UU No. 41 Tahun 2004). Artinya, instansi untuk benda bergerak berupa uang adalah Lembaga Keuangan Syari'ah.

\section{Maslahah dalam Hukum Islam}

\section{Pengertian Maslahah}

Menurut pengertian lughat (bahasa), lafal maslahah bermakna kemanfaatan atu kebaikan. Ia satu wazan dengan lafal manfa'ah. Dalam bahasa Indonesia, lafal maslahah ditulis dengan maslahat (lawan dari mafsadat), yang bermakna sesuatu yang mendatangkan kebaikan (keselamatan), faedah, guna. Sementara itu, kemaslahatan bermakna kegunaan, kebaikan, manfaat, kepentingan.

Maslahah dalam pengertian istilah (terminologi), para pakar mengartikan sebagai berikut:

a. al-Ghazali

Maslahah adalah suatu 'ibarah (ungkapan) tentang mendatangkan manfaat dan menghindarkan mafsadat (kerusakan). al-Ghazali memaknai maslahah bukan dalam pengertian yang biasa dipakai dalam masyarakat ('urf), tetapi manfaat dalam pengertian shara', yaitu memelihara agama, jiwa, akal, keturunan, dan harta benda. ${ }^{25}$ Dengan demikian, mafsadat bermakna sesuatu yang dapat merusak salah di antara lima hal yang disebut dengan al-maqasid al-shar'iyyah (al-Satibi), al-usul al-khamsah, kulliyyat al-khams, usul alshar'iyyah, al-daruriyyah al-khamsah (al-Ghazali), yaitu memelihara agama, jiwa, akal, keturunan, dan harta benda. Untuk itu, tidak semua yang bermanfaat itu dikategorikan maslahah, tetapi harus selaras dengan shara'. Artinya, maslahah tidak boleh dipahami hanya untuk sesuatu yang bermanfaat bagi manusia (makhluk), lebih-lebih manfaat yang didorong oleh dominasi hawa nafsu yang terkadang mengalahkan pertimbangan akal sehat. Misalnya, minum arak itu mendatangkan kemaslahatan bagi manusia, tetapi tidak dianggap maslahah oleh Shari' (Khaliq).

b. Al-Khawarizmi

Maslahah adalah menjaga tujuan shara' dengan cara menghindarkan mafsadat dari manusia. Walaupun pengertian al-Khawarizmi ini lebih sempit dari al-Ghazali, yakni dar' almafsadah saja, tetapi ia tidak dapat dipisahkan dengan jalb al-maslahah. Hal ini, karena jalb al-maslahah baru dapat dicapai dengan mendahulukan dar' al-mafsadah, sehingga muncul kaidah dar' almafsadah muqaddam 'ala jalb al-maslahah. ${ }^{26}$

\footnotetext{
${ }^{25}$ Yusuf Hamid al- 'Alim, al-Maqasid al- 'Ammah (Kairo: Dar al-Hadith, t.t), 134-135.

${ }^{26}$ Ibid., 135. Said Aqil al-Munawwar, Konsep al-Maslahat dalam Hukum Islam (Suatu Tinjauan sebagai Sumber Hukum Islam) dalam Dimensi-Dimensi Kehidupan dalam Perspektif Islam (Malang: Pascasarjana UNISMA, 2001), 36.
} 
c. Sa'id Ramadan al-Buti

Maslahah adalah sesuatu yang bermanfaat, yang dimaksudkan oleh Shari' (Allah dan Rasul-Nya) untuk kepentingan hamba-Nya, baik dalam menjaga agama, jiwa, akal, keturunan dan harta benda mereka, berdasarkan urutan tertentu yang termuat dalam pemeliharaan tersebut ${ }^{27}$. Dengan demikian, maslahah tidak boleh lepas dari tujuan yang ingin dicapai oleh shara', tidak semata-mata kemanfaatan yang sesuai dengan akal semata.

Dari paparan tersebut, ternyata para ulama memasukkan maqasid al-shari'ah ke dalam lima sasaran, yaitu memelihara agama, jiwa, akal, keturunan, dan harta benda, sehingga disebut dengan al-maqasid al-khamsah. Padahal, ada ulama yang memasukkan memelihara kehormatan (al- 'ird $\}$ ) ke dalam al-maqasid alshar'iyyah, sehingga disebut al-maqasid al-sittah. Untuk itu, mengapa mereka tidak memasukkan al- 'ird dalam al-maqasid al-shar'iyyah. Abd. al-Wahhab alKhallaf dalam kitabnya "Ilmu Usul al-Fiqh" ${ }^{28}$ memasukkan al- "ird pada urutan keempat dalam al-maqasid al-khamsah, tidak memasukkan al-nasl (dimasukkan pada urutan kedua, yaitu al-nafs). Sementara itu, al- 'Attar dalam Hashiyyah Jam' al-Jawami', menempatkan al- 'ird sejajar dengan al-mal dalam urutan kelima (aldin, al-nafs, al- 'aql, al- 'ird wa al-mal wa al-'ird\}). ${ }^{29}$

\section{Macam-macam Maslahah}

Ulama membagi maslahah ke dalam beberapa segi, yaitu (1) berdasarkan tujuan zaman/waktunya, (2) berdasarkan tingkat kebutuhannya, (3) berdasarkan cakupannya, (4) bedasarkan ada atau tidaknya perubahan, dan (5) berdasarkan ada atau tidaknya syarat dalam penetapannya.

Berdasarkan tujuan zamannya, maslahah terbagi menjadi maslahah dunia dan akhirat. Maslahah dunia adalah kewajiban atau aturan shara' yang terkait dengan hukum-hukum mu'amalah, sedangkan maslahah akhirat adalah maslahah yang terkait hukum-hukum tentang akidah (tauhid) dan ibadah (mahdah). Pembagian ini ditentang oleh Sa'id Buti, karena menurutnya bahwa apa yang ditetapkan shara', baik di bidang akidah, ibadah atau mu'amalah, pada hakikatnya bertujuan merealisasikan kemaslahatan manusia, baik di dunia maupun akhirat.

Berdasarkan tingkat kebutuhannya dalam menjaga lima tujuan shara', maslahah terbagi menjadi 3 (tiga) bagian, yaitu (1) maslahah daruriyyah (kemaslahatan primer), ${ }^{30}$ yaitu kemaslahatan yang bersifat mutlak harus terjaga terhadap lima pokok (agama, jiwa, akal, keturunan, dan harta benda), yang jika diabaikan maka akan timbul kekacauan dalam kehidupan keagamaan dan

\footnotetext{
27 Ramdan al-Buti. Dawabit al-maslahah fi al-Shari'ah al-Islamiyyah (Beirut: Muassasat alRisalah, 1992), 27.

${ }^{28}$ Abd al-Wahhab Khallaf, Ilmu Usul al-Fiqh (Mesir: Dar al-Qalam, 1978), 200,

${ }^{29} \mathrm{Abd}$ al-Hamid Abu al-Maka>rim, al-Adillah al-Mukhtalaf fiha wa atharuha fi al-fiqh al-Islami (Kairo: Dar al-Islam, t.t), 71.

${ }^{30}$ Maslahah daruriyyah ini dikenal dengan istilah "maslahah dar' al-mafasid", yakni menolak halhal yang dapat merusakkan sendi-sendi agama yang berjumlah lima (al-maqasid al-khamsah). Muhammad al-Amin bin al-Shawqiti, Muthsakhinat Usul al-Fiqh (Madinah: al-Jami'ah alIslamiyyah bi al-Madinah al-Munawwarah, t.t), 169 sebagaimana dikutip oleh Saifuddin Zuhri dalam bukunya Ushul Fiqih Akal Sebagai Sumber Hukum Islam (Yogyakarta: Pustaka Pelajar, 2009), 104.
} 
keduniaan manusia; (2) maslahah hajiyyah (kemaslahatan skunder), ${ }^{31}$ yaitu kemaslahatan yang diperlukan seseorang untuk memudahkan dalam kehidupan dan menghilangkan kesulitan dalam rangka memelihara lima unsur, sedang jika tidak dilakukan maka tidak menimbulkan kekacauan, tetapi hanya menimbulkan kesulitan dan kesempitan; dan (3) maslahah tahsiniyyah (maslahah tersier) ${ }^{32}$, yaitu memelihara kelima unsur pokok dengan cara meraih dan menetapkan hal-hal yang pantas dan layak dari kebiasaan-kebiasaan hidup yang baik serta menghindarkan sesuatu yang dipandang sebaliknya oleh akal sehat. Jika maslahah tahsiniyyah ini tidak tercapai, maka manusia tidak sampai mengalami kesulitan, tetapi mereka dianggap menyalahi nilai-nilai kepatutat dan tidak mencapai taraf hidup bermartabat.

Ketiga macam maslahah (daruriyyah, hajiyyah, dan tahsiniyyah) saling terkait antara satu dengan lainnya dalam pelaksanaannya, sehingga perintah Shari', baik berupa melakukan sesuatu atau tidak melakukan dapat dilakukan secara utuh. Bahkan, maslahah tahsiniyyah ini akan memperkokoh yang daruri (primer), sehingga dalam ibadah misalnya tidak hanya lahirnya saja, tetapi batinnya. Memakai pakaian yang baik dan bersih (tahsiniyyah) dalam shalat akan memperkokoh maslahah-maslahah sebelumnya (hajiyyah dan daruriyyah), sehingga dirinya terasa berada di hadapan Allah dan berpengaruh dalam kehidupan sehari-harinya. Oleh karena itu, tahsiniyyah sebagai penyempurna hajjiyyah dan hajjiyyah sebagai penyempurna daruriyyah, karena daruri merupakan maslahah asliyyyah. ${ }^{33}$

\section{Analisis Maslahah dalam Wakaf Muaqqat}

Wakaf merupakan salah satu amal berupa infak ke jalan Allah swt. Al-Qur'an menyatakan agar benda yang diinfakkan tergolong harta yang paling disenangi sebagaimana dalam surat Ali 'Imran (3): 92:

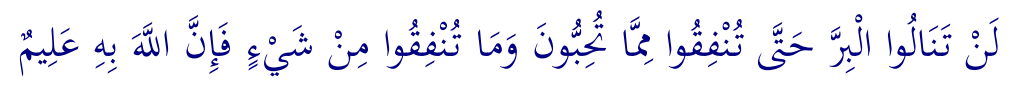

"Kamu tidak akan memperoleh kebajikan, sebelum kamu menginfakkan harta yang kamu cintai. Dan apa yang kamu infakkan tentang hal itu, sungguh Allah Maha Mengetahui"

Dengan ayat ini, jelaslah bahwa seseorang tidak akan mencapai tingkatan kebjikan di hadapan Allah, sebelum dia ikhlas menginfakkan harta yang dicintainya di jalan Allah. Ayat ini sangat terkait dengan perintah Allah pada surat al-Baqarah (2): 267

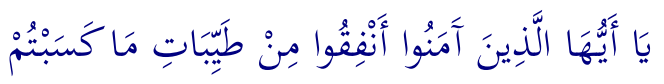

"Wahai orang-orang yang beriman! Infakkanlah sebagian hasil usahamu yang baik-baik)"

\footnotetext{
${ }^{31}$ Maslahah hajiyyah ini dikenal dengan istilah "maslahah ahjalb al-masalihy", yakni mendatangkan kemaslahatan yang akan menopang maslahah daruri, sehingga tidak timbul berbagai kesulitan, kepicikan, dan kesusahan (raf'al-haraj wa daf'al-mashaqqah). Ibid. 105

${ }^{32}$ Maslahah tahsiniyyah ini dikenal dengan istilah "maslahah tamamiyyah", yang bersifat komolementer bagi manusia, yang sebaiknya dilakukan jika diinginkan suatu kesempurnaan dan kelengkapan dalam kehidupan. Ibid. 106.

${ }^{33}$ Abd. al-Hamid, al-Adillah, 65.
} 
Setelah turun surat Ali 'Imran (3): 92, para shahabat nabi Muhammad saw. berlomba-lomba berbuat kebajikan, Abu Talhah al-Ansari, seorang hartawan di kalangan shahabat Ansar datang kepada nabi Muhammad saw. menyerahkan sebidang tanah kebun kurma di Madinah. Tanah ini merupakan tanah yang terbaik, yang berada di depan masjid Madinah, yang airnya selalu diminum oleh Nabi dan dikenal dengan sebutan kebun Bayruha'. Bahkan, sewaktu Abu Talhah menyerahkan kepada Nabi, beliau berkata: Bakh Bakh (kata-kata yang menunjukkan kerelaan dan kekaguman). Sewaktu Abu Talhah mendengar perkataan beliau dan dia berkehendak agar kebun tersebut diinfakkan kepada kerabatnya, Rasulullah saw. menerimanya. Kemudian kebun itu diberikan kepada kerabat Abu Talhah, yaitu Hassan bin Thabit dan Ubay bin Ka'ab. Hal ini menunjukkan kebaikan menginfakkan harta kepada seorang yang masih ada hubungan kerabat, sehingga dia mendapat pahala sedekah dan mempererat hubungan silaturrahmi dengan kerabatnya. Begitu juga, shahabat Umar bin Khattab menginfakkan sebagian kebunnya yang berada di Khaybar dengan sabda nabi Muhammad saw. Habbis al-asl wa sabbil al-thamrah ${ }^{34}$ (pegang pokoknya dan gunakan buahnya sebagai sedekah). Artinya, nabi memerintah pula agar kebun itu tetap dipeliharanya, sedangkan hasil kebun itu sebagai infak (wakaf) dari Umar. Hadis ini dijadikan dalil oleh ulama yang menyatakan bahwa benda wakaf itu tidak lepas dari pemiliknya. Sementara itu, ulama lain menyatakan, bahwa benda tersebut sudah lepas dari pemiliknya, hanya saja benda tersebut tidak boleh dipindahkan ke lainnya seperti dijual. Termasuk juga Zayd bin Harithah yang menginfakkan kudanya (sabl namanya) walaupun kuda yang diberikan kepada Rasulullah (infak/wakaf) itu akhirnya dikembalikan lagi. ${ }^{35}$

Ketiga peristiwa yang termuat dalam hadis menunjukkan bahwa infak itu sebaiknya memperhatikan keluarga, jangan kepada orang lain dan sekaligus menunjukkan adanya infak (wakaf) ahli atau dhurri sebagaimana dalam bahasan kitab salaf, berbeda dengan bahasan wakaf dalam kitab fiqh kontemporer. Hal ini sejalan dengan pemikiran ulama yang menyatakan bahwa nabi memberikan sedekah (wakaf) kepada kerabat orang yang bersedekah itu karena dua faktor, yaitu (1) sedekah kerabat itu lebih utama, dan (2) dengan sedekah kepada keluarga, jiwa pemberi sedekah lebih nyaman dan terjauh dari penyesalan. ${ }^{36}$

Di negara-negara muslim, termasuk Indonesia, wakaf ahli/dhurri ditiadakan, sehingga yang termuat dalam hukum positif, hanya wakaf khayri, yang menitikberatkan pada kepentingan umum, seperti masjid, lembaga pendidikan, dan jalan desa. Indonesia telah mengatur perwakafan secara teratur, baik sebelum merdeka maupun setelah merdeka, bahkan dengan lahirnya UU No. 14 Tahun 2004 tentang Wakaf, Indonesia telah benar-benar mengatur wakaf dalam hukum positif, produk Dewan Perwakilan Rakyat.

Pasal 1 ayat 1 UU Nomor 14 Tahun 2004 tentang Wakaf, bahwa batas peruntukkan wakaf tidak hanya yang muabbad (selama-lamanya), tetapi dapat

\footnotetext{
${ }^{34}$ Dalam redaksi lain berbunyi "Habbis al-asl wa tasaddata biha", pegang pokoknya dan sedekahkan hasilnya. Ibn Abi Shaybah menjelaskan bahwa permulaan wakaf dalam Islam adalah sedekah (wakaf) Umar dan al-Shafi'i berkata bahwa wakaf merupaka amal yang hanya ada pada Islam, belum ada pada masa Jahiliyyah. Al-San'ani, Subul al-Salam, vol. 3 (Jedah: al-Haramayn, 1960), 87.

35 al-Razi, al-Tafsir al-Kabir, vol. 4 (Beirut: Dar al-Fikr, 1994), 147.

${ }^{36}$ Wahbah al-Zuhayli, al-Tafsir al-Munir, vol. 3 (Beirut: Dar al-Fikr, 1991), 294.
} 
dilakukan muaqqat (ditentukan waktunya). Hal ini telah merubah aturan wakaf di Indonesia yang muabbad sebagaimana dalam PP No. 28 Tahun 1977 dan Kompilasi Hukum Islam. Artinya, wakif atau keluarganya dapat menikmati kembali harta bendanya (mawquf), sehingga harta benda dapat dinikmati oleh pihak yang menerima, karena telah mengambil manfaat dari mawquf, bahkan jika dikelola secara baik, hasilnya sudah beranak pinak. Sementara itu, wakif dapat menikmati kembali mawquf, lebih-lebih jika wakif ini terjadi kebangkrutan atau sakit-sakitan dan tidak mempunyai biaya perawatan. Sementara itu, jika wakif telah meninggal dunia, maka mawquf ini dapat dijadikan sebagai harta tinggalan mayit (wakif), lebih-lebih jika keluarganya terjadi kemiskinan, sehingga tidak dapat menikmati pendidikan yang wajar.

Dimuatnya wakaf muaqqat di samping muabbad dalam UU No. 14 Tahun 2004 tentang Wakaf ini memberikan kesempatan kepada wakif untuk memikirkan dua hal, yaitu mendekatkan diri (taqarrub) kepada Allah dengan infak (wakaf), mengamalkan apa diperintahkan Shari' melalui Alqur'an dan Hadis, sebagaimana dalam surat al-Baqarah (2): 267 dan Ali 'Imran (3): 92. Manfaat dari harta yang diinfakkan atau diwakafkan dapat dirasakan oleh orang banyak, seperti wakaf tanah atau uang untuk masjid, mushalla, lembaga pendidkan, dan wc umum, sehingga aplikasi ajaran Islam dapat terlihat dalam masyarakat. Sementara itu, wakif juga mempunyai keluarga yang harus dipelihara, baik fisik maupun rohani, yang tidak boleh diabaikan, sehingga keluarga tidak terperosok pada jurang api neraka, sebagaimana firman Allah dalam surat al-Tahrim (66)): 6, yang berbunyi: ya ayyuha al-ladhina amanu qu anfusakum wa ahlikum naran (Wahai orangorang yang beriman! Peliharalah dirimu dan keluargamu dari api neraka). ${ }^{37}$ Ayat ini harus dipahami secara seksama dengan menggunakan kaidah amar "al-amr bi al-shay' amr bi wasailih (memerintah sesuatu berarti memerintah sarananya). Untuk itu, hal-hal yang terkait dengan perlindungan keluarga dari api neraka harus dilakukan, di antaranya harus mempunyai biaya untuk pendidikan. Biaya ini akan tertutupi jika mempunyai harta, karena harta merupakan salah satu dari sesuatu yang dapat menstabilkan keluarga, sebagaimana al-Qur'an mensifati harta benda dengan "al-lati ja'ala Allah lakum qiyaman" setelah lafal "wa la tu'tu al-sufaha'a amwalakum" dalam surat al-Nisa' (4): 5.

Al-Zuhayli menjelaskan makna dari lafal "al-lati ja'ala Allah lakum qiyaman" dengan pernyataan bahwa harta benda adalah tonggak kehidupan, sebagai penyebab kebaikan kehidupan rumah tangga, dan keteraturan segala perkara. Dengan harta, bangsa menjadi maju dan terbangun peradaban, dan dengan harta individu dan kelompok menjadi bahagia, serta dapat mengalahkan musuh. Bahkan ulama salaf berkata: Harta benda adalah senjata dan sungguh saya meninggalkan harta yang menyebabkan saya dihisab oleh Allah adalah lebih baik daripada saya membutuhkan pertolongan orang lain. ${ }^{38}$

\footnotetext{
${ }^{37}$ Dalam ayat ini, Allah memerintahkan orang-orang yang beriman agar menjaga dirinya dari api neraka, juga memerintahkan untuk mengajarkan kepada keluarganya taat dan patuh kepada perintah Allah untuk menyelamatkan mereka dari api neraka. Dalam hal ini, keluarga merupakan amanat yang harus dipelihar kesejahteraannya, baik jasmani maupun rohani. Salah satu cara menyelamatkannya memerintah keluarga untuk dan bersabar sebagaimanan dalam surat Taha (20): 132 dan al-Shu'ara' (26): 214.

${ }^{38}$ al-Zuhayli, al-Tafsir al-Munir, vol. 4 (Beirut: Dar al-Fikr, t.t), 249.
} 
Dengan melihat fungsi harta benda tersebut, seorang wakif jangan sampai harta bendanya dihabiskan semua, karena hanya terdorong ingin mengharapkan keridlaan dan pahala dari Allah, tanpa peduli terhadap dirinya dan keluarganya. Sementara itu, jika wakif meninggal dunia dan keluarga wakif hidupnya normal, maka tidak ada masalah dengan wakaf muabbad. Akan tetapi, jika wakif dalam keadaan miskin atau sengsara setelah mewakafkan benda, atau keluarganya lemah baik lahir maupun batin, maka wakaf muabbad ini akan dapat menimbulkan kegoncangan rumahtangga, bahkan dapat menjadi kafir, sebagaimana hadis yang menyatakan bahwa kefakiran itu hampir saja mendatangkan kekafiran (kada alfaqr an yakuna kufran).

Sayyid Sabiq, ${ }^{39}$ menyatakan bahwa seseorang diharamkan mewakafkan sesuatu yang dapat membahayakan ahli waris, berdasarkan hadis Rasulullah saw. "la darar wa la dirar" (tidak boleh berbuat bahaya kepada dirinya sendiri dan orang lain). Selanjutkan, Sayyid Sabiq mengutip pendapat pengarang kitab alRawdah al-Nadiyyah sebagai berikut:

"Secara garis besar dinyatakan bahwa wakaf-wakaf yang dimaksudkan untuk memutuskan apa yang diperintahkan Allah untuk dilakukan dan menentang halhal yang diwajibkan-Nya, maka dianggap batal demi hukum, sama sekali tidak terjadi. Hal ini sebagaimana orang yang mewakafkan kepada anak-anak laki-laki, bukan anak-anak perempuan dan hal-hal yang serupa. Perbuatan yang dilakukan orang tersebut tidak berkehendak mendekatkan diri kepada Allah, melainkan berkendak menentang hukum-hukum Allah dan melawan terhadap apa yang disyari'atkan Allah kepada para hamba-Nya. Dia menjadikan wakaf yang bersifat Taghut sebagai jalan untuk menuju Syetan". Hendaknya hal ini selalu diingat, karena pada zaman ini banyak sekali terjadi. Begitu juga wakaf yang dilakukan sesesorang hanya cinta agar harta bendanya tetap berada pada keturunannya, tidak keluar dari pemilikan mereka. Hal demikian ini hanya dimaksudkan menentang hukum Allah, yaitu pindahnya kepemilikan melalui pewarisan dan menyerahkan urusannya kepada ahli waris untuk melakukannya. Tidaklah urusan kaya atau fakir miskin mereka sebagai urusan wakif, tetapi urusan Allah. ${ }^{40}$

Wakaf muaqqat ini dapat dilakukan analog (qiyas) dengan pembatasan wasiat atau dalalat al-nas\} (teori Hanafiyyah), maksimal 1/3 harta yang dimiliki, sebagaimana dalam hadis Sa'ad bin Abi Waqqas. Bahkan nabi Muhammad saw. mengatakan kepada Sa'ad, bahwa $1 / 3$ itu sudah banyak (diucapkan tiga kali), kemudian beliau bersabda "Innaka 'an tadhara warastatak aghniya'a khayr min an tadhararahum 'alah yatakaffafu al-nas" ${ }^{41}$, sungguh kamu meninggalkan keluargamu dalam keadaan kaya adalah lebih baik daripada meninggalkan mereka dalam keadaan meminta-minta kepada orang lain.Artinya, hadis ini memerintahkan untuk memperhatikan keluarga jangan sampai hidup memintaminta kepada orang lain. ${ }^{42}$ Di samping itu, dengan dibatasi $1 / 3$, keluarga, lebihlebih anak masih mendapat sisanya dan tidak berdampak kemarahan kepada orang tua, karena hartanya tidak habis. Dalam hal wakaf muaqqat keluarga masih dapat

\footnotetext{
${ }^{39}$ Sayyid Sabiq, Fiqh al-Sunnah, vol. 3 (Beirut: Dar Fikr, 1977), 387.

${ }^{40}$ Ibid.

${ }^{41}$ Ibn Hajar al- 'Asqalan, Bulugh al-Maram min Adillat al-Ahkam (Mekah: al-H\}aramayn, t.t), 206.
} 
menikmati harta orang tua yang menjadi obyek wakaf. Hal ini menunjukkan, bahwa memelihara keluarga perlu dijaga (muhafazah 'ala al-nasl), sebagaimana termuat dalam maqasid al-khamsah.

Jika wasiat (maqis 'alayh) sebagaimana hadis tersebut dibatasi, karena pertimbangan keluarga, maka wakaf muaqqat (maqis) juga karena pertimbangan keluarga. Artinya, 'illat al-hukm antara keduanya berupa maslahah fi muhafazzat al-nasl. Untuk itu, memelihara keluarga wakif dengan memperhatikan harta benda akan menopang jiwa dan agama mereka, sebagai maqadari sid daruriyyah yang berada pada tingkat yang lebih tinggi. Walaupun wakaf muaqqat berada pada tingkatan maqasid hajiyyah, tetapi dalam keadaan tertentu dapat dimasukkan dalam kategori maqasid daruriyyah. Untuk itu, jika wakaf muaqqat yang berada pada tingkatan hajiyyah diabaikan atau tidak diperhatikan, hanya muabbad saja, maka akan dapat mengganggu yang daruriyyah. Karena itu, wakaf muaqqat sebagaimana termuat dalam Pasal 1 ayat 1 Undang-Undang Nomor 41 Tahun 2004 dapat mengandung manfaat atau kemaslahatan yang besar sekali dalam menjaga keluarga yang ditinggalkan wakif, sehingga wakif akan mendapat beberapa pahala, yaitu manfaat wakaf muaqqat, berupa:

1. Pahala yang akan diterimanya setelah meninggal dunia, yang berasal dari amalnya sendiri,

2. Manfaat dari keluarganya, yang menyedahkan hartanya (yang dulunya sebagai mawquf) dan pahalanya diperuntukkan wakif, dan

3. Manfaat do'a dari keluarga wakif setelah meninggal dunia, karena keluarganya telah menjadi orang yang saleh, karena mereka dibesarkan melalui pendidikan, yang di antaranya berasal dari harta yang dahulunya dijadikan obyek wakaf.

Dengan demikian, wakaf muaqqat ini akan memperoleh keuntungan pahala bagi wakif, sebagaimana hadis yang diriwayatkan imam |Abu Dawud:

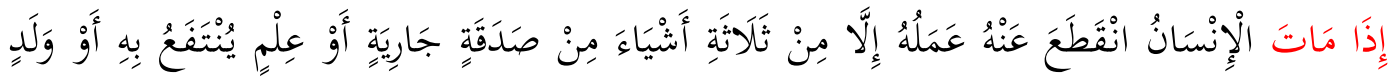

$$
\begin{aligned}
& \text { صَالِحِ يَلْعُوِ لَهُ }
\end{aligned}
$$

Cara pembatasan (muaqqat) pada wakaf harus dilihat benda yang dijadikan obyeknya. Jika benda tidak bergerak berupa tanah, maka jangan disertifikatkan ke Badan Pertanahan Nasional, sebab akan terjadi pemindahan hak milik untuk selamanya, tetapi dengan pembuatan akta ikrar tanah wakaf yang dibatasi waktunya. Sedangkan, untuk wakaf uang harus ditentukan pada sertifikat muaqqat pada Lembaga Keuangan Syari'ah sebagai diatur dalam peraturan perundangundangan yang berlaku.

\section{E. Kesimpulan}

4. Ulama berbeda pendapat tentang wakaf muaqqat (berjangka):

a. Shafi'iyah dan Hanabilah berpendapat bahwa wakaf tidak boleh dibatasi waktunya, sehingga jika suatu benda telah diwakafkan, maka benda tersebut sudah lepas dari pemiliknya dan tidak tidak dapat ditarik kembali 
oleh wakif. Artinya, setelah terjadi ikrar wakaf dari wakif, maka langsung terjadi peristiwa hukum yang mengikat (lazim), yang berarti berlaku selamanya (muabbad).

b. Malikiyyah dan Hanafiyyah berpendapat bahwa benda yang diwakafkan belum lepas dari milik wakif, sehingga dapat ditarik kembali oleh wakif sebagaimana pinjaman (āriyah). Begitu juga, benda yang diwakafkan tidak harus miliknya wakif sendiri, tetapi dapat juga dari benda yang disewakan.

5. Wakaf muaqqat yang terdapat dalam Pasal 1 (1) Undang-Undang Nomor 1 Tahun 2004 tergolong mukhafazah 'ala al-nasl (memelihara keturunan) dalam tingkatan maslahah hajiyyah (sekunder), yang berfungsi sebagai penyempurna maslahah daruriyyah (primer). 


\section{DAFTAR KEPUSTAKAAN}

Abdurrahman. 1992. Kompilasi Hukum Islam di Indonesia. Jakarta: Akademika Prassindo.

al- 'Alim, Yusuf Hamid. t.th. al-Maqasid al- 'Ammah, Kairo: Dar al-Hadith.

Anshori, Abdul Ghafur. 2006.Hukum dan Praktik Perwakafan di Indonesia. Yogyakarta: PDOP.

al- 'Asqalani, Ibn Hajar. t.th. Bulugh al-Maram min Adillat al-Ahkam. Mekah: alHaramayn.

al-Buti, Ramadan. 1992. Dawabit al-maslahah fi al-Shari'ah al-Islamiyyah, Beirut: Muassasat al-Risalah

Departemen Agama, 2006. Bunga Rampai Perwakafan Jakarta: Direktorat Jenderal Bimbingan Masayarakat Direktorat Pemberdayaan Wakaf.

2006. Fiqih Wakaf, Jakarta: Proyek Peningkatan Zakat dan Wakaf Jenderal Bimas Islam dan Penyelenggaraan Haji.

Khallaf, Abd al-Wahhab. 1978. Ilmu Usul al-Fiqh, Mesir: Dar al-Qalam.

al-Makarim, Abd al-Hamid Abu. t.th. al-Adillah al-Mukhtalaf fiha wa atharuha fi al-figh al-Islami. Kairo: Dar al-Islam.

al-Munawwar, Said Aqil.2001. Konsep al-Maslahat dalam Hukum Islam (Suatu Tinjauan sebagai Sumber Hukum Islam) dalam Dimensi-Dimensi Kehidupan dalam Perspektif Islam, Malang: Pascasarjana UNISMA.

al-Razi, 1994. al-Tafsir al-Kabir, vol. 4. Beirut: Dar al-Fikr.

Rofiq, Ahmad. 2003. Hukum Islam di Indonesia, Jakarta: RajaGrafindo Persada.

Sabiq, Sayyid. 1977. Fiqh al-Sunnah, vol. 3. Beirut: Dar al-Fikr.

Al-San'ani. 1960. Subul al-Salam, vol. 3. Jedah: al-Haramayn.

al-Sharqawi. T.th. al-Sharqawi 'ala al-Tahrīr. Juz 2. Singapura: al-Haramain.

Said, Umar. 1997. Hukum Islam di Indonesia. Surabaya: CV Cempaka.

al-Shanqiti, Muhammad al-Amin. t.th. Muthsakhinat Usul al-Fiqh. Madinah: alJami'ah al-Islamiyyah bi al-Madinah al-Munawwarah.

Sjarif, Surini Dahlan.1984. Intisari Hukum Benda, Jakarta: Ghalia Indonesia.

Tim Redaksi, 1996. Kamus Besar Bahasa Indonesia, cet. ke-7. Jakarta: Balai Pustaka.

Usman, Suparman. 1999. Hukum Perwakafan di Indonesia. Serang: Darul Ulum. al-Zuhayli, Wahbah. 1991. al-Tafsir al-Munir, vol. 3. Beirut: Dar al-Fikr.

al-Fikr. 1997. al-Fiqh al-Islām wa Adillatuh. vol. 9. Beirut: Da>r

Zuhri, Saifuddin. 2009. Ushul Fiqih Akal Sebagai Sumber Hukum Islam. Yogyakarta: Pustaka Pelajar. 